\title{
EFFECT OF SILDENAFIL ON ERECTILE DYSFUNCTION IN SPINAL CORD INJURED PATIENTS
}

\author{
B. K. MANOU ${ }^{1}$, P. N. VAN TAM ${ }^{2}$, M.B. SESAY ${ }^{3}$, P.A. JOSEPH ${ }^{4}$, D. A. ALLOH ${ }^{1}$, J. BOMBO ${ }^{1}$. J. \\ KOUAKOU ${ }^{1}$, B. M. NANDJUI ${ }^{1}$
}

\begin{abstract}
${ }^{1}$ Department of the nervous system and rehabilitation, faculty of medicine, university of Cocody, Abidjan; ${ }^{2}$ UGECAM Aquitaine Centre de La Tour de Gassies - 33523 BRUGES Cedex, France ; ${ }^{3}$ Service d'Anesthésie-réanimation, GH Pellegrin, Centre Hospitalier Universitaire -33076 Bordeaux cedex, France and $^{4}$ Service de Médecine Physique et de Réadaptation, Pôle de Neurosciences Cliniques GH Pellegrin \& EA 4136 Handicap et système nerveux Université Victor Segalen Bordeaux2, Centre Hospitalier Universitaire F33076 Bordeaux cedex, France
\end{abstract}

Corresponding author: Dr Benjamin Manou

E.mail: benmanou@yahoo.fr

Conflict of interest: None declared

\section{SUMMARY}

Background: Erectile dysfunction is a preoccupying issue, just like motor and bladder disability, in spinal cord injured (SCI) patients. This is particularly so because of the increasing prevalence of paraplegic and tetraplegic subjects and the fact that these patients are younger, and sexually active.

Objective: To determine the effects of Sildenafil (Viagra $^{\mathbb{R}}$ ) on erectile dysfunction in SCI patients.

Methods: After medical ethics committee approval and informed patient consent, we conducted a prospective inquiry between January and March 2007 in 16 SCI patients who were under Sildenafil treatment for erectile dysfunction. An abridged version of the International Index of Erectile Function (IIEF-5) questionnaire was completed the patients.

Results: The mean age (range) of the patients was 32.75 yrs (21-53 yrs). The mean duration of their disability was 47.75 months ( $4 \mathrm{yr}$ ). Trauma was the etiology in $87.5 \%$ of the cases (44\% were road accidents). $12 / 16$ patients were paraplegics (10 above T10) and 4 were tetraplegics ( 1 above $\mathrm{C} 4$ and 3 below $\mathrm{C} 5$ ). The mean duration of sildenafil treatment was 18.75 months (17 days- $7 \mathrm{yr}$ ). $70 \%$ of the patients were satisfied with their erection after treatment. However, 10/16 patients had concomitant treatment with alprostadil. Conclusion: Sildenafil is a vasoactive drug which can be used as a simple, discrete and effective treatment for erectile dysfunction in SCI patients. This approach is compatible with the efforts to improve the quality of life and rehabilitation of these patients.

Keywords: paraplegia, spinal cord injury, erectile dysfunction, Sildenafil

\section{INTRODUCTION}

Care of spinal cord injured (SCI) patients is a major preoccupation regarding sexuality, motor and bladder dysfunctions. This is particularly so because of the increasing prevalence of paraplegic and tetraplegic subjects and the fact that these patients are younger, and sexually active. This increase in prevalence is directly related with the increase in life expectancy of these patients irrespective of the etiology. In fact, an inquiry conducted in France, in 2002, showed an incidence of $19.4 /$ million inhabitants and a prevalence of $100-400 /$ million regarding post trauma paraplegic and tetraplegic subjects. ${ }^{1}$

Erectile and ejaculation disorders in these patients require effective management in order to improve their social and familial rehabilitation. This preoccupation, shared by many research and healthcare teams has led, in the past years, to the use of vasoactive drugs like Sildenafil in view of improving the sexuality of patients with erectile dysfunction. ${ }^{2,3}$ The objective of this study was to determine the effects of Sildenafil on erectile dysfunction in SCI patients.

\section{MATERIALS AND METHODS}

The study was approved by the ethics committee of the University of Bordeaux. Informed patient consent was obtained prior to data collection. From January to March 2007, we conducted an inquiry in 16 SCI paraplegic and tetraplegic male patients who were either currently or previously admitted (2000-2007) at the Tour de Gassies Rehabilitation Center of Bordeaux/France. The inclusion criteria were male SCI patients who had been or currently treated by Sildenafil for erectile dysfunction. None SCI patients and those incapable of completing the questionnaire were excluded. 
A questionnaire based on the concise version of the International Index of Erectile Function (IIEF-5) ${ }^{4}$ was sent by ordinary mail to some patients while others received the questionnaire on site. This 5-item questionnaire has been validated by the National Institutes of Health Consensus Panel. Additionally we assessed patient satisfaction. The data was analyzed using the EPI info 2000 software. The results were expressed as mean and standard results were expressed as mean and standard deviation or range.

\section{RESULTS}

The mean age (range) of the patients was 32.75 yrs (21-53 yrs). The mean duration of their disability was 47.75 months ( 4 yr). Trauma was the etiology in $87.5 \%$ of the cases (44\% were road accidents). $12 / 16$ patients were paraplegics (10 above T10) and 4 were tetraplegics ( 1 above $\mathrm{C} 4$ and 3 below $\mathrm{C} 5$ ). The mean duration of sildenafil treatment was 18.75 months (17 days-7 yr). $70 \%$ of the patients were satisfied with their erection after treatment. However, 10/16 patients had concomitant treatment with alprostadil.

Table 1 Clinical characteristics of the study population $(\mathrm{N}=16)$

\begin{tabular}{|l|l|l|}
\hline Clinical Characteristic & $\begin{array}{l}\text { Number of } \\
\text { patients }\end{array}$ & $\begin{array}{l}\text { Percent } \\
(\mathbf{\%})\end{array}$ \\
\hline Duration of evolution & \multicolumn{2}{|l|}{} \\
\hline$<12$ months & 5 & 31.25 \\
\hline $1-5$ yrs & 6 & 37.50 \\
\hline
\end{tabular}

The main characteristics of the study population are shown in Table 1. The prescription and distribution profiles of sildenafil are presented in Table 2. The main responses of the patients are shown in Table 3.

Table 2 Distribution and utilization of Sidenafil

\begin{tabular}{|l|l|l|}
\hline Treatment & $\begin{array}{l}\text { Number } \\
\text { of pa- } \\
\text { tients }\end{array}$ & $\begin{array}{l}\text { Percent } \\
(\%)\end{array}$ \\
\hline Duration of Treatment \\
\hline$<1$ month & 4 & 25 \\
\hline $1-2$ months & 7 & 43.75 \\
\hline$>12$ months & 5 & 31.25 \\
\hline Prescription & 14 & 87.5 \\
\hline Physiotherapist & 14 & 12.5 \\
\hline General practitioner & 2 &
\end{tabular}

\section{DISCUSSION}

This study shows that sildenafil is an effective treatment of erectile dysfunction in SCI patients. The study population is comparable to other series including Tetrafigap, ${ }^{1}$ Hulting $^{3}$ and Giuliano ${ }^{6}$ with regard to young age and the fact that trauma was the major cause of the spinal cord lesion. ., $^{-9}$
Table of 3: Erectile dysfunction according to the IIEF 5 Classification

\begin{tabular}{|c|c|c|}
\hline Items & $\begin{array}{l}\text { Patients } \\
(n=16)\end{array}$ & $\begin{array}{l}\text { Percent- } \\
\text { age }(\%)\end{array}$ \\
\hline \multicolumn{3}{|l|}{$\begin{array}{l}\text { Q1. How do you rate your con- } \\
\text { fidence that you could get and } \\
\text { keep an erection? }\end{array}$} \\
\hline Not sure at all & 10 & 62.5 \\
\hline Not very sure & 3 & 18.75 \\
\hline Quite sure & 2 & 12.5 \\
\hline Sure enough & 1 & 6.25 \\
\hline \multicolumn{3}{|l|}{$\begin{array}{l}\text { Q2. When you had erections } \\
\text { with sexual stimulation, how } \\
\text { often were your erections hard } \\
\text { enough for penetration (intro- } \\
\text { duction of the penis into the } \\
\text { vagina)? }\end{array}$} \\
\hline Never & 2 & 12.25 \\
\hline Sometimes & 2 & 12.25 \\
\hline Most times & 3 & 18.75 \\
\hline Always & 9 & 56.25 \\
\hline \multicolumn{3}{|l|}{$\begin{array}{l}\text { Q.3 during sexual intercourse, } \\
\text { how often were you able to } \\
\text { maintain your erection after } \\
\text { you had penetrated (entered) } \\
\text { your partner? }\end{array}$} \\
\hline Never & 2 & 12.25 \\
\hline A few times & 8 & 50 \\
\hline Sometimes & 3 & 18.75 \\
\hline Most times & 2 & 12.25 \\
\hline Always & 1 & 6.25 \\
\hline \multicolumn{3}{|l|}{$\begin{array}{l}\text { Q.4 During sexual intercourse, } \\
\text { how difficult was it to maintain } \\
\text { your erection to completion of } \\
\text { intercourse? }\end{array}$} \\
\hline No attempt & 2 & 12.25 \\
\hline Extremely difficult & 2 & 12.25 \\
\hline Slightly difficult & 4 & 25 \\
\hline Not difficult & 8 & 50 \\
\hline \multicolumn{3}{|l|}{$\begin{array}{l}\text { Q5. When you attempted sexual } \\
\text { intercourse, how often was it } \\
\text { satisfactory for you? }\end{array}$} \\
\hline No attempt & 2 & 12.25 \\
\hline Rare & 1 & 6.25 \\
\hline Sometimes & 2 & 12.25 \\
\hline Most times & 2 & 12.25 \\
\hline Always & 9 & 56.25 \\
\hline
\end{tabular}

However the evolution period of the disorder was shorter than in Tetrafigap's series.

In this study, sildenafil was mainly prescribed by physiotherapists. These specialists are more concerned with the sexual disorders of SCI patients. 
In fact, the French Society of Urology recommended this approach with the physiotherapist in the frontline. ${ }^{10}$ However, the important role of general practitioners could not be totally excluded.

The response to the IIEF-5 questionnaire corroborate to previous studies of Giuliano and Hulting., ${ }^{3,6}$ We used the IIEF-5 questionnaire because it is an auto evaluation form with a high degree of sensitivity and specificity in detecting the efficacy of treatment. It is not specifically designed for SCI patients. It consists of 5intems derived from 15 of the complete version. This questionnaire takes into account four of the five areas of sexual function: erection, orgasm, sexual desire. ${ }^{4}$ This concise version is simple and fast to use during consultation. The first item of the HEF- 5 deals with the pretreatment status while the four other questions involve the post-treatment status of the patients.

We also added questions on global satisfaction so that the patients could compare their erectile conditions before and after sildenafil treatment. Despite the high satisfaction rate of our patients, 10/16 of them used other vasoactive drugs like alprostadil (edex). The main explanation for this was that sildenafil was not reimbursed by the French social welfare. The majority of the patients expressed their desire for the reimbursement of this drug in SCI patients. Patients who failed both the sildenafil and alprostadil were advised to consult our local multidisciplinary team of physiotherapists, neurosurgeons and anesthesiologists in order to determine whether they were suitable candidates for implantable sacral nerve stimulators. However, we did not assess the outcome of these consultations.

The results of this study are strictly in the hospital domain and could not be extrapolated to all SCI patients. Additionally, the sample size is too small to deduce any pertinent conclusions. However, our study provides further insight to the efficacy of Sildenafil on erectile dysfunction of SCI patients in corroboration with other studies. ${ }^{2}$

\section{REFERENCES}

1. Albert T, Ravaud JF, and TETRAFIGAP group. Rehabilitation of spinal cord injury in France, a nationwide multicentre study of incidence and regional disparities. Spinal Cord 2005; 43: 356-365.

2. Goldstein I, Lue TF, Padma-Nathan H, Rosen RC, Steers WD, Wicker PA. Sildénafil par voie orale dans le traitement de la dysfonction erectile. $N$ Engl J Med 1998, 338: 1397-1404.

3. Hultling C, Giuliano F, Quirk F, Pena B, Mishra A, Smith MD. Quality of life in patients with spinal cord injury receiving Viagra (Sildenafil citrate) for the treatment of erectile dysfunction. Spinal Cord 2000; 38: 363-370.

4. Rosen RC, Riley A, Wagner G, Osterloh IH, Kirkpatrick J, Mishra A. The International Index of Erectile Function (IIEF): a multidimensional scale for assessment of erectile dysfunction. Urology 1997, 49: 822-829.

5. Rosen RC, Cappelleri JC, Smith MD, Lipsky J. Pena BM. Development and evaluation of an abridged, 5-item version of the International Index of Erectile Function (IIEF-5) as diagnostic tool for erectile dysfunction. Int $J$ Impot Res 1999, 11: 319-326.

6. Giuliano F, Hulting C, El Masry WS, Smith MD, Osterloh IH, Orr M, Maytom M. Randomised trial of sildenafil for the treatment of erectile dysfunction in spinal cord injury. Sildenafil Study Group. Ann Neurol 1999, 46: 15-21.

7. Held JP, Dizien O. Clinical aspects and early evaluation of functional impairment in paraplegic patients. Rev Prat 1988; 38:1796-800.

8. Alexander MS, Alexander CJ. Recommendations for discussing sexuality after spinal cord injury/dysfunction in children, adolescents, and adults. J Spinal Cord Med. 2007; 30 Suppl 1:S65-70.

9. François N, Kunstmann JM. Management of reproduction disorders in spinal cord injured adolescents. Gynecol Obstet Fertil 2005, 33: 620-623.

10. Cour F, Fabbro-Peray P, Cuzin B et al. Recommendations to general practice doctors for first line management of erectile dysfunction. Prog Urol 2005; 15: 1011-1020. 